\title{
Price, Quality Products, Quality Services and Locations on Customer Satisfaction in Indonesian Culinary
}

\author{
Ravindra Safitra Hidayat, Ratih Puspitaningtyas Faeni
}

\begin{abstract}
Food and beverages are a major need for human beings. The development of culinary business makes the competition more and more intense, all efforts strive to attract consumers and retain customers in various ways. Consumers also now have begun carefully in choosing a place to eat, not only the product into consideration but the price, quality of service and location also a consideration of consumers in choosing a place to eat. Therefore, this study was made to determine the effect of price, product quality, service quality and location to customer satisfaction. The population in this study were the visitors at Indonesian Culinary Centers. The sample in this research is 100 respondents taken by simple random sampling technique. The research instrument used as a measuring tool in this study is in the form of questionnaire. Results of respondents on the questionnaire given then processed using Microsoft Excel 2007 software and software SPSS 19. The results of the analysis in this study yields regression equation is $Y=-$ $4.717+(0.039) X 1+0.333 X 2+0.368 X 3+0.245 X 4$. Product quality variables, service quality and location partially have a significant influence on customer satisfaction in Indonesian Culinary Centers. Price variables partially have an insignificant effect on customer satisfaction in Indonesian Culinary Centers. Conclusion that can be taken from the research result that is according to the consumer, the three independent variables (Product Quality, Service Quality and Location) are considered important as determinant of consumer satisfaction, while Price variable does not affect customer satisfaction in Indonesian Culinary Centers.
\end{abstract}

\section{Introduction}

\subsection{Research Background}

In the era of globalization a progressive changes that occur in the business world. These changes are characterized by technological advances, increasingly advanced societal thinking patterns and lifestyles that are influenced by globalization. Changes that change in the environment demand to keep up with it in everyday life. Influence of the development of the times that occurred seen with the increasing number of offerings of goods and services [1-5]. This makes consumers have an alternative choice of goods and services that will be consumed. For manufacturers this is a threat, because the more goods and services offered, the more intense the competition that occurs in the business world [6].

One of the fastest growing businesses is the food business known as culinary, because food and drink is one of the main human needs. The need for food and beverages increases with the increasing number of people in Indonesia, causing entrepreneurs to start a business in the culinary field, because it is considered to have a huge opportunity. It is an important thing for entrepreneurs to know the needs of consumers by making innovations and good service for the company to remain competitive. The more culinary variety presented and the growing number of outlets that serve the culinary, the attraction of writers to examine about the culinary business that is focused on one type of culinary steak [7-11].

Basically the higher the level of competition that occurs, it will be more and more alternatives or options that can be selected by consumers to choose products in accordance with the wishes and expectations. The result is that consumers become more selective and careful in choosing every product offered. Consumers who choose a restaurant as their place to eat will pay attention to things like price, product quality, service quality, and also location of the company. Therefore, the company must continue to pay attention to every detail that exists to satisfy consumers in order to compete to seize many customers [12-16].

In determining the price of products that want to be marketed and give the maximum contribution for consumers interested in the marketed products and see the surrounding community to be adjusted in determining the price of the product. Employers also need to think about setting the selling price of their products appropriately, because improper prices will result in not attracting buyers to buy the goods [17-20]. 
1. Product quality can also be an indicator in consumer satisfaction, if the product has a high quality then the higher the satisfaction consumers get. At this time already many restaurants provide good quality products to attract the purchase of the product and make consumers feel satisfied.

2. The quality of services provided by food service companies can also provide input to the service company's income, because with the service provided by the company to consumers, the consumer will feel cared for and feel comfortable in the services provided by the company.

3. In addition, the company must also have an appropriate location strategy so that it will provide its own advantages for the company. With the right location then the consumer will be easy to reach the location [21-25].

\subsection{Problem Identification}

In Research limited problems in order not to expand, the issues to be studied include:

Focus on price (X1), product quality (X2), service quality (X3), location (X4), and consumer satisfaction (Y) in Indonesian Culinary.

Research conducted in Indonesian Culinary Centers.

\subsection{Research Framework}

Source : Primary Resources, 2017

\subsection{Hypothesis}

According Sugiyono (2010: 93): "Hypothesis is a temporary answer to the formulation of research problems, therefore the formulation of the problem is usually arranged in the form of a question sentence. It is said temporarily, because the given answer is based on a relevant theory, not yet based on empirical facts obtained through data collection [26-28].

To test independent variable to dependent variable, hypothesis is needed as follows: How influence of Price, Product Quality, Service Quality, and Location to Consumer Satisfaction in Waroeng Steak \& Shake, Jakarta, Indonesia [29].

\section{Literature Review}

\subsection{Price}

According to Tjiptono \& Candra (2012: 315): "Price can be interpreted as the amount of money (monetary unit) and / or other aspects (non-monetary) containing certain utilities or utilities necessary to obtain a product". Meanwhile, according to Sunyoto (2012: 315): "Price can be interpreted as the amount of money needed to get a certain number of products or a combination of goods and services, the price is a component that directly affects the company's profits.

\subsection{Product Quality}

According to Abdullah and Tantri (1012: 159): "The quality of the product is one of the important tools for marketers to establish the position. When developing a product, the marketer must first select the level of quality that will support the product's position in the target market. Product quality means the product's ability to perform its function ". Meanwhile, according to Kotler and Armstrong (2012: 283): "Product quality is the ability of a product to perform its functions, including durability, reliability, accuracy, ease of operation and improvement, and other valuable attributes".

\subsection{Service Quality}

According to Thamrin Abdullah and Francis Tantri (2012: 44): "Quality is the overall characteristic of a good or service that affects its ability to satisfy both the stated and the implied needs". Meanwhile, according to Lewis and Booms (1983) in Fandy Tjiptono and Gregorius Candra (2011: 180): "Defining service quality as a measure of how well the level of service provided is capable, in accordance with customer expectations".

\subsection{Location}

According to Lupiyoadi (2013: 92): "location is a decision made by the company in relation to which operations and staff will be placed". Meanwhile, according to Hurriyati (2010: 55): "location is related to the decision made by the company regarding where the operations and staff will be placed, the most important of the location is the type and level of interaction between service providers and customers related to site selection".

\subsection{Customer Satisfaction}

Understanding satisfaction according to Philip Kotller and Kevin Lane Keller (2009: 138): "In general satisfaction is the feeling of pleasure or disappointment of someone who arises Karen compare perceived performance of products (or outcomes) to their expectations". Understanding consumers according to Kotler and Keller (2009: 166): "All individuals or households who buy or obtain goods or services for personal consumption". Understanding customer satisfaction by Kotler in the book Sunyoto (2013: 35): "Consumer satisfaction is the level of one's feelings after comparing (performance or results) are perceived compared to expectations. Consumers can experience one of the three levels of general satisfaction that if the performance is below expectations, consumers will feel disappointed but if the performance in accordance with customer expectations will feel satisfied and what if the performance can exceed expectations then the customer will feel very happy or satisfied".

\section{Research Methodology}

\subsection{Type of Research}

This research uses the help of analysis with software program Microsoft Excel 2007 and Statistic Product Service (SPSS) version 19.0. Processed data is data obtained from the primary data in the form of questionnaires that have been disseminated and in answer by 100 respondents who have been tabulated. Analyzer used is multiple 
regression analysis with the help of interpretation of interval value with likert scale. The product quality, service quality and location variables have a significant effect on customer satisfaction Indonesian Culinary Centers. Price variables partially have no significant effect on customer satisfaction. Simultaneously (together) price variable (X1) product quality (X2) service quality (X3) and location (X4) have significant effect to customer satisfaction (Y) at Indonesian Culinary Centers, Jakarta, Indonesia.

\subsection{Data Collection Method}

In doing this research, as for data collection techniques used, including:

\subsubsection{Field study}

Direct survey in the field of Indonesian Culinary Centers in Jakarta, Indonesia

\subsubsection{Interview}

Interview by holding question and answer or ask questions to employees of Indonesian Culinary Centers. Directly to collect the required information.

\subsubsection{Observation}

Observations or observations made on the object of research is Indonesian Culinary Centers.

\subsubsection{Library search}

Reference books relating to the material discussed for obtaining secondary data information in the final drafting.
Questionnaires were diatributed to consumers so that the authors get direct data from consumers more accurate and reliable. Questionnaire display is designed by using a specific statement (Likert scale) in the table table so that it can facilitate the respondents to choose among several proposed alternatives.In addition, there is also a preface that informs the purpose of research and the description of filling questionnaires in each variable studied.

\subsection{Population and Sampling}

The population is consumers who have bought food and beverage productson sources obtained from consumers, consumers who come to buy food products are 1200 people every day, so in 1 month calculated from 30 active working days (1200 people x 30 days $=36000$ people), and in doing 3 months of research assumed 10800 people out of the results (36000 people x 3 months $=108000$ people). In conducting this research, the authors use Simple Random Sampling technique, with the determination of the number of samples using Taro Yamane's formula.

So by using the above formula Taro Yamane of the population of 10800 obtained a sample of 999.08 and in to 1000 respondents.

\subsection{Research Object}

Research done inseveral Indonesian Culinary Centers in Jakarta, Indonesia.

Results and Discussion Multiple Linear Regression Analysis

Multiple Linear Regression Analysis

\subsubsection{Quistionaires Distribution}

Coefficients $^{\mathrm{a}}$

\begin{tabular}{|c|c|c|c|c|c|c|c|}
\hline \multirow[t]{2}{*}{ Model } & \multicolumn{2}{|c|}{$\begin{array}{l}\text { Unstandardized } \\
\text { Coefficients }\end{array}$} & $\begin{array}{l}\text { Standardiz ed } \\
\text { Coefficient s }\end{array}$ & \multirow[t]{2}{*}{$\mathrm{T}$} & \multirow[t]{2}{*}{ Sig. } & \multicolumn{2}{|c|}{$\begin{array}{l}\text { Collinearity } \\
\text { Statistics }\end{array}$} \\
\hline & $\mathrm{B}$ & Std. Error & Beta & & & Tolerance & VIF \\
\hline \multirow{5}{*}{$\begin{array}{l}\text { 1(Constant) } \\
\text { Price } \\
\text { Product Quality } \\
\text { Service Quality } \\
\text { Location }\end{array}$} & -4.717 & 2.079 & & -2.268 & .026 & & \\
\hline & -.039 & .078 & -.038 & -.503 & .616 & .836 & 1.197 \\
\hline & .333 & .087 & .336 & 3.835 & .000 & .632 & 1.581 \\
\hline & .368 & .078 & .372 & 4.737 & .000 & .787 & 1.271 \\
\hline & .245 & .079 & .248 & 3.117 & .002 & .765 & 1.307 \\
\hline
\end{tabular}

a. Dependent Variable: customer_satisfaction

Source: Output SPSS, 2017

$Y=-4.717+(-0.039) X_{1}+0.333 X_{2}+0.368 X_{3}+0.245 X_{4}$

Regression equation:

Constanta -4.717 means: if Price (X1), Product Quality (X2), Quality of Service (X3), and Location (X4) value is 0 (no additions), Consumer Satisfaction (Y) is decreased by 4,717 .

Price Variable coefficient (X1) of -0.039 gives the meaning that Price (X1) has a negative effect on Consumer Satisfaction (Y). This shows that with the addition of 1 unit price, there will be a decrease in Consumer Satisfaction of 0,039 and vice versa.

Coefficient variable of Product Quality (X2) of 0.333 gives the meaning that Product Quality (X2) have positive effect to Consumer Satisfaction (Y). This shows that with

the addition of 1 unit of Product Quality, there will be an increase in Consumer Satisfaction of 0.333 and vice versa.

Quality Service Quality (X3) coefficient of 0.368 means that Quality of Service (X3) has a positive effect on Consumer Satisfaction (Y). This shows that with the addition of 1 Unit Quality of Service, there will be an increase in Consumer Satisfaction of 0.368 and vice versa.

Location Location (X4) coefficient of 0.245 gives the meaning that Location (X4) has a positive effect on Consumer Satisfaction (Y). This shows that with the addition of 1 unit Location, there will be an increase in Consumer Satisfaction of 0.245 and vice versa. 


\subsection{Coefficient Determination}

Model Summary

\begin{tabular}{|l|l|l|l|l|}
\hline Model & $\mathrm{R}$ & R Square & $\begin{array}{l}\text { Adjusted R } \\
\text { Square }\end{array}$ & $\begin{array}{l}\text { Std. Error of the } \\
\text { Estimate }\end{array}$ \\
\hline 1 & $.734^{\mathrm{a}}$ & .539 & .520 & .681811 \\
\hline
\end{tabular}

a. Predictors: (Constant), Location, Price, Services_Quality, Product_Quality

b. Dependent Variable: Customer Satisfaction

Source: Hidayat, Output SPSS, 2017

The value of $\mathrm{R}$ is a multiple correlation, ie the correlation between two or more independent variables to $\mathrm{t}$-Test (Partial Test)

Coefficients ${ }^{\mathrm{a}}$ Partial Analysis

\begin{tabular}{|c|c|c|c|c|c|c|c|c|}
\hline \multicolumn{2}{|c|}{ Model } & \multicolumn{2}{|c|}{ Unstandardized Coefficients } & $\begin{array}{l}\text { Standardized } \\
\text { Coefficients } \\
\text { Beta }\end{array}$ & $\mathrm{t}$ & Sig. & \multicolumn{2}{|c|}{ Collinearity Statistics } \\
\hline \multirow{5}{*}{1} & (Constant) & -4.717 & 2.079 & & -2.268 & 026 & & \\
\hline & Price & -.039 & .078 & -.038 & -.503 & .616 & .836 & 1.197 \\
\hline & Product Quality & .333 & .087 & .336 & 3.835 & .000 & .632 & 1.581 \\
\hline & Service Quality & .368 & .078 & .372 & 4.737 & .000 & .787 & 1.271 \\
\hline & Location & .245 & .079 & .248 & 3.117 & .002 & .765 & 1.307 \\
\hline
\end{tabular}

a. Dependent Variable: Customer Satisfaction

Source: Hidayat, Output SPSS, 2017

the dependent variable. $\mathrm{R}$ value ranges from 0 to 1 . If close to 1 then the relationship is getting closer, but if close to 0 then the relationship is getting weaker. In the table above shows that the value of $\mathrm{R}$ of 0.734 close to number 1 , so it can be said that the relationship between price variables, product quality, service quality and location with consumer satisfaction variables quite closely. From the table above obtained the coefficient of determination or adjust R. Square (R2) of 0,520 or $52 \%$, the figure shows $52 \%$ variable Consumer satisfaction is explained by the variable Price, Product Quality, Service Quality, and Location. While the remaining $48 \%$ is explained by other factors not included in this study.
1. Price $\left(\mathrm{X}_{1}\right)$

Based on the above table states that Price variable does not have significant effect on Consumer satisfaction (Y). Because the value of $\mathrm{t}$ count is $-0,503<1,987$ and Sig. $0.616>0.05$ so Ho is accepted, so it can be concluded that the price is partially no significant effect on Consumer Satisfaction.

\section{Product Quality $\left(\mathrm{X}_{2}\right)$}

Based on the above table states that the variable of Product Quality has significant effect on Consumer satisfaction (Y). Because the tcount of 3.835> 1.987 and Sig. $0.000<0.05$ so Ho is rejected, so it can be concluded that Product Quality partially significant effect on Consumer Satisfaction.

\section{Service Quality $\left(\mathrm{X}_{3}\right)$}

Based on the above table states that variable Quality of Service has significant influence on Consumer satisfaction (Y). Because the tcount of 4.737> 1.987 and Sig. 0.000 $<0,05$ so Ho is rejected, so it can be concluded that Service Quality partially significant to Consumer Satisfaction.

\section{Location $\left(\mathrm{X}_{4}\right)$}

Based on the above table states that the variable Location significantly influenced on consumer satisfaction (Y). Because the tcount of 3.117> 1.987 and Sig. $0.002<0.05$ so Ho is rejected, so it can be concluded that Location partially significant effect on Consumer Satisfaction.

\section{f-Test (Simultant)}

ANOVA $^{\mathrm{b}}$ f-Test Simlutant Analysis

\begin{tabular}{|l|l|l|l|l|l|}
\hline Model & $\begin{array}{l}\text { Sum of } \\
\text { Squares }\end{array}$ & Df & $\begin{array}{l}\text { Mean } \\
\text { Square }\end{array}$ & F & Sig. \\
\hline $\begin{array}{l}\text { 1. Regression } \\
\text { Residual }\end{array}$ & 51.732 & 4 & 12.933 & 27.821 & $.000^{\mathrm{a}}$ \\
\cline { 2 - 6 } & 44.162 & 95 & .465 & & \\
\hline
\end{tabular}
\begin{tabular}{|l|l|l|l|l|}
\hline Total & 95.894 & 99 & & \\
\hline
\end{tabular}
a. Predictors: (Constant), Location, Price, Services Quality,
Product Quality

b. Dependent Variable: Customer Satisfaction

Source: Hidayat, Output SPSS, 2017

Analysis of coefficient determination Anova

- $\quad$ f-Test $(27,821)>$ f-table $(2,47)$ à $\mathrm{H}_{0}$ rejected and $\mathrm{Ha}$ accepted and significant significant

Sig $(0,000)<0,05$ à $\mathrm{H}_{0}$ rejected and $\mathrm{Ha}$ accepted

This means that the independent variables of Price (X1), Product Quality (X2), Quality of Service (X3), and Location (X4) have a Significant Influence on Consumer Satisfaction (Y) simultaneously.

\section{Conclusions}

This study aims to determine whether there is influence of variable Price, Product Quality, Service Quality, and Location of Consumer Satisfaction in Waroeng Steak \& Shake Kebayoran branch, South Jakarta. From the formulation of the proposed research problem can be known the influence of the four independent variables, the results of hypotheses and data analysis that has been done in the discussion in the previous chapter, can be drawn the conclusions of this study are as follows:

1. Price Influence (X1) on Consumer Satisfaction (Y): Price is not significant effect on customer satisfaction in Indonesian Culinary.

2. The Effect of Product Quality (X2) on Consumer Satisfaction (Y): 
Product Quality partially significant effect on customer satisfaction in Indonesian Culinary.

3. The Influence of Service Quality (X3) on Consumer Satisfaction (Y):

Quality Service is partially significant effect on customer satisfaction in Indonesian Culinary.

4. Location (X4) to Consumer Satisfaction (Y):

Location in Indonesian Culinary partially significant effect on customer satisfaction in Indonesian Culinary.

5. Price Influence (X1), Product Quality (X2), Quality of Service (X3), Location (X4) on Customer Satisfaction (Y):

Price, Product Quality, Service Quality and Location at Indonesian Culinary simultaneously have a significant effect on customer satisfaction in Indonesian Culinary.

\subsection{Suggestions}

Based on the conclusions obtained in this study, the suggestions as a complement to the results of research that can be given as follows:

1. Indonesian Culinary price should be affordable.

2. The quality of products in Indonesian Culinary should pay attention to the taste and appearance of the product for the improvements.

3. Indonesian Culinary should be further improved the quality of service to consumers such as speed and responsiveness in serving consumers so that they feel more satisfied with the service received.

4. Location is should be strategic, so should pay attention to the area.

Suggestions for further research

For further research that has variables and similar methods, researchers suggest to further expand the object of research and add or use other variables that may affect consumer satisfaction.

Ethical clearance - Not required

Source of funding- Self

Conflict of Interest - Nil

\section{References}

[1] Ahmad Subagyo. Marketing In Business Edisi 1. Jakarta: Mitra Wacana Media, 2010.

[2] Ali Hasan. Marketing dan Kasus-Kasus Pilihan. Cetakan ke 2. Yogyakarta: Center for Academic Publishing Service, 2014

[3] Arief Rakhman Kurniawan.Total Marketing Cetakan Ke 1. Yogyakarta : PT. Buku Kita, 2014.

[4] Basu Swastha Dhammesta. Manajemen Pemasaran. Edisi ke 2. Jakarta: Universitas Terbuka, 2011.

[5] Buchari Alma. Manajemen Pemasaran dan Jasa. Bandung: Alfabeta, 2013.

[6] Danang Sunyoto. Dasar-Dasar Manajemen Pemasaran. Yogyakarta: CAPS, 2012.

[7] Duwi Priyatno. SPSS 22 Pengolah Data Terpraktis. Yogyakarta: CV. ANDI, 2014.

[8] Fandy Tjiptono. Pemasaran Jasa. Yogyakarta: CV. ANDI, 2011.

[9] Fandy Tjiptono. Pemasaran Jasa. Malang: Bayumedia, 2012.

[10] Fandy Tjiptono dan Gregorius Chandra. Service, quality \& satisfactionEdisi 3.Yogyakarta: ANDI, 2011.
[11] Fandy Tjiptono dan Gregorius Chandra. Pemasaran Strategik Edisi 2. Yogyakarta: CV. ANDI, 2012.

[12] Hurryati, Ratih. Bauran Pemasaran Jasa dan Loyalitas Konsumen Bandung: Alfabeta, 2010.

[13] Istijanto. Aplikasi Praktis Riset Pemasaran. Jakarta : PT. Gramedia Pustaka Umum, 2005

[14] Heizer, Jay dan Barry Render. Manajemen Operasi. Jakarta: Mitra Wacana Media, 2010.

[15] Kotler, Philip dan Gary Amstrong. Prinsip-Prinsip PemasaranEdisi 12. Jakarta :Erlangga, 2008

[16] Kotler, Philip dan Kevin Lane Keller. Manajemen Pemasaran Edisi 13, Jakarta: Erlangga, 2009.

[17] Kotler, Philip dan Kevin Lane Keller. Manajemen Pemasaran. Alih bahasa oleh Bob Sabran. Edisi 13. Jakarta: Erlangga 2012.

[18] Kotler, Philip dan Kevin Lane Keller. Manajemen Pemasaran.Alih bahasa oleh Bob Sabran Edisi 13, Jilid 1. Jakarta: Erlangga, 2013.

[19] Rambat Lupiyoadi dan A.Hamdani. Manajemen Pemasaran Jasa Edisi 2. Jakarta: Salemba Empat, 2011.

[20] Rambat, Lupiyoadi. Manajemen Pemasaran Jasa Berbasis Kompetensi. Jakarta: Salemba Empat, 2013.

[21] Riduwan dan Engkos Achmad Kuncoro. Path Analysis (Analisis Jalur) Cetakan 3. Bandung : CV. ALFABETA, 2011.

[22] Riduwan. Dasar-Dasar Statistika Edisi Revisi. Bandung: CV. ALFABETA, 2014

[23] Siregar, Syofian. Metode Penelitian Kuantitatif. Jakarta: Kencana Pernadamedia Group, 2013.

[24] Siregar, Syofian. Statistika Deskriptif Untuk Penelitian. Cetakan ke 4. Jakarta: PT. RajaGrafindo Persada, 2014.

[25] Sugiyono. Metode Penelitian Kuantitatif, Kualitatif, dan R\&D Bandung: Alfabeta, 2010

[26] Susatyo Herlambang. 2014. Basic Marketing(Dasar-Dasar Pemasaran) Cara Mudah Memahami Ilmu Pemasaran. Cetakan Pertama 2014. Yogyakarta: Pustaka Baru Press.

[27] Sugiyono. Metode Penelitian Kuantitatif, Kualitatif dan R \& D. Bandung: Alfabeta, 2011.

[28] Sugiyono. Metode Penelitian Kombinasi (Mixed Method). Bandung Alfabeta, 2013.

[29] Thamrin, Abdullah dan Francis Tantri. Manajemen Pemasaran. Jakarta: PT. RajaGrafindo Persada, 2012 